\title{
Roman Monogamy
}

\author{
Laura Betzig \\ Evolution \& Human Behavior Program, Unversity of Michigan, \\ Ann Arbor, Michigan
}

\begin{abstract}
Mating in Rome was polygynous; marrage was monogamous. In the years $18 \mathrm{BC}$ and AD 9 the first Roman emperor, Augustus, backed the lex Julıa and the lex Papia Poppaea, his "moral" legislation. It rewarded members of the senatorial aristocracy who married and had children; and it punished celibacy and childlessness, which were common. To many historians, that suggests Romans were reluctant to reproduce. To me, it suggests they kept the number of their legitimate children small to keep the number of their illegitimate children large. Marriage in Rome shares these features with marrage in other empires with highly polygynous matmg: inheritances were raised by inbreeding; relatedness to heirs was rased by marrying virgins, prassing and enforcing chastity in married women, and discouraging widow remarriage; heirs were limitedand inheritances concentrated-by monogamous marrage, patriliny, and primogeniture; and back-up heirs were got by divorce and remarriage, concubinage, and adoption. The "moral" legislation interfered with each of these. Among other things, it diverted inheritances by making widows remarry; it lowered relatedness to heirs by making adultery subject to public, rather than private, sanctions; and it dispersed estates by making younger sons and daughters take legitimate spouses and make legitimate heirs. Augustus' "moral" legislation, like canon law in Europe later on, was not, as it first appears, an act of reproductive altruism. It was, in fact, a form of reproductive competition.
\end{abstract}

KEY WORDS: Law, Inheritance, Succession. Marriage. Family. Roman history

I n $31 \mathrm{BC}$, Octavian put an end to the civil wars by beatıng Antony at Actıum In $27 \mathrm{BC}$, he took the title "Augustus" and became the first Roman emperor In $\Lambda \mathrm{D} 9$, he stood before the knights in the Forum. lined up the bachelors on one side and fathers on the other The bachelors far outnumbered the fathers So to the fathers he offered "love and praise," "prizes," "honors and offices," for the bachelors he had harsh words. He said,

mine has been an astonıshing experience, for though I am always doing everything to promote an increase of population among you and am now

Recelved December 31, 1991 , revised June 18, 1992

Address reprint requests to Laura Betzıg, Evolution \& Human Behavior Program, 100H Rackham Bldg University of Michıgan Ann Arbor MI 48109 
about to rebuke you, I grieve to see that there are a great many of you We do not spare murderers, you know Yet, if one were to name over all the worst crimes, the others are as naught in comparison with this one you are now committing, whether you consider them crime for crime or even set all of them together over against this single crime of yours For you are committıng murder in not begettıng in the first place those who ought to be your descendants, you are committing sacrilege in putting an end to the names and honours of your ancestors, and you are guilty of impiety in that you are abolıshing your families, overthrowing their rites and their temples Moreover, you are destroying the State by disobeyıng its laws, and you are betraying your country by rendering her barren and childless, nay more, you are layıng her even with the dust by making her destitute of future inhabitants

(Dio, History, Iv1 4-5) In $18 \mathrm{BC}$ and AD 9, Augustus backed the lex Julta de maritandis ordinibus, the lex Papia Poppaea, and the lex Julla de adulteris, his "moral" legislation Among other thıngs, it punıshed bachelors politically, socially, and economically, and it rewarded fathers

Were Romans really reluctant to reproduce? Some seem to think so The younger Plıny refers to the "tedıum and hard work" of raisıng chıldren, Suetonius says Hortalus, a young senator "whom Augustus' impassioned pleas had encouraged to rear four children," was impoverished by them (Pliny, Letters, 1 8, Suetonius, Tiberius, 47) Contraception, abortion, and abandonment were common (e g, Hopkıns 1965a, Wiedemann 1989, Boswell 1988) When rich men raised families at all, they tended to be very small (e g , Carcopıno 1940 90-91, Fontanılle 1977, Hopkıns 1983)

I think there's plenty of evidence that Romans were not at all reluctant to raise lots of illegitımate children-especially by their slaves (Betzig, this volume) Augustus, however. did not reward fathers for rearıng bastards, in fact, in the lex Papıa Poppaea of AD 9, illegitımate children were explıcitly kept off the burth register (e g , Digest $27122-3,50525$, see Rawson 1989 24,28 ) What the emperors wanted was that Romans rear more herrs

That's what they were reluctant to do Objections to, demonstrations against, and circumventions of the "moral" laws are alluded to in Livy, Horace, Ovid, Plıny, Martial, Juvenal, Tacitus, Suetonıus, and Cassıus Dio, to name a few To get the laws passed at all, Augustus had to go around the senate to the tribal assembly (Mommsen 1955) Why? I thınk Roman fathers, like fathers across empires, limited the number of their heirs in order to ralse the inheritances they left them I'm not the only one to think so As early as the second century BC, Polybius, a Greek historian in Rome, said people were reluctant to raise more than a few children "so as to leave them in affluence," as late as the fourth century AD St Augustıne said "fertility is a bother to wealthy people," meanıng a limited hereditas would get split up (Polybius, Histories, xxxv1 17 7, Augustıne, En Psalm, 137 8, in Shaw 1987a 43) But I'd go further I thınk people kept the number of their heirs small in order to keep the number of their bastards large, I thınk they married monogamously so they could mate polygynously 
Marriage in Rome had a lot in common with marriage in other empires (Table 1). First, inheritances were increased by inbreeding-even incestamong the aristocracy, and by early marriage--even infant betrothalamong the elite Second, relatedness to heirs was ensured by choosing young brides and preferning virgins, by keeping wives indoors or under guard, and by ideologies enthusiastic about chastity Third, efforts were made to concentrate inheritance on a single heir, by patrilıny-which excluded daughters, by primogeniture- - which excluded younger sons, and by monogamywhich excluded children by every mate but one legitımate wife Last, in case a wife falled to bear and rear an heir, back-up heirs were gotten by divorce and remarriage, by concubinage, and by adoption Marriage legislation in Rome interfered with each of these Among other things, the effect of the "moral" legislation was to tower inheritances, by discouraging inbreeding and infant betrothal, to lower paternity confidence, by making adultery a public rather than a private crime, to ralse the number of heirs, and so dimınısh the size of estates, by deterring patrilıny and primogeniture, and to lower the odds of getting a contungency heir by divorce

Why did marriage legislation take this form in Rome, and not in other cmpires? I think the obvious answer is that Augustus was the first Roman emperor In spite of all the rhetoric about restoring the republic, the point of the empire was to put an end to it. That meant an end to the more equal distribution of power that came to manifest itself as anarchy and civil war, it meant the start of the less equal distribution of power that came to manifest itself as imperial law It meant the fall of many clans, it meant the rise of a few Pax et Princeps As Sir Ronald Syme put it in his Roman Revolution, "In the beginning kıngs ruled at Rome, and in the end, as was fated, it camc round to monarchy again Monarchy brought concord 'Cum domino pax ista ventt" " (1939. 9)

Peace came in many ways There were purges of men in high office rich rivals were killed; and their estates were confiscated (e g, Suetonıus, Tacitus, Cassius Dio) 'There was a rise in the number of oftices there were more and more consuls, praetors, senators, and eventually even citizens, and every honor was cheaper (e g, Hopkıns 1983) There was the sumptuary and related legislation that kept the rich from fighting as gladiators, sponsoring too many games, having extravagant weddıngs, eatıng flashy food, wearing showy clothes, being interred in big tombs, and so on (e g , Garnsey 1970) And there was the "moral" legislation the aristocracy was asked to prolıferate Augustus' "moral" laws were antıcıpated by centuries of sanctions against celıbacy, among other things, and they were followed by centuries of legislation that stopped with Constantine's conversion of the Roman state to the Catholic church (e g , Csillag 1976, Brunt 1971, Treggiar1 1991a) As Theodore Mommsen put it in his Romisches Strafrecht, they were "one of the most intrusive and long-lasting creations in crimınal law in all history" (Mommsen 1955. 691, translated in Cohen 1991 124)

Did they hasten the aristocracy's demise? This paper reviews Roman 


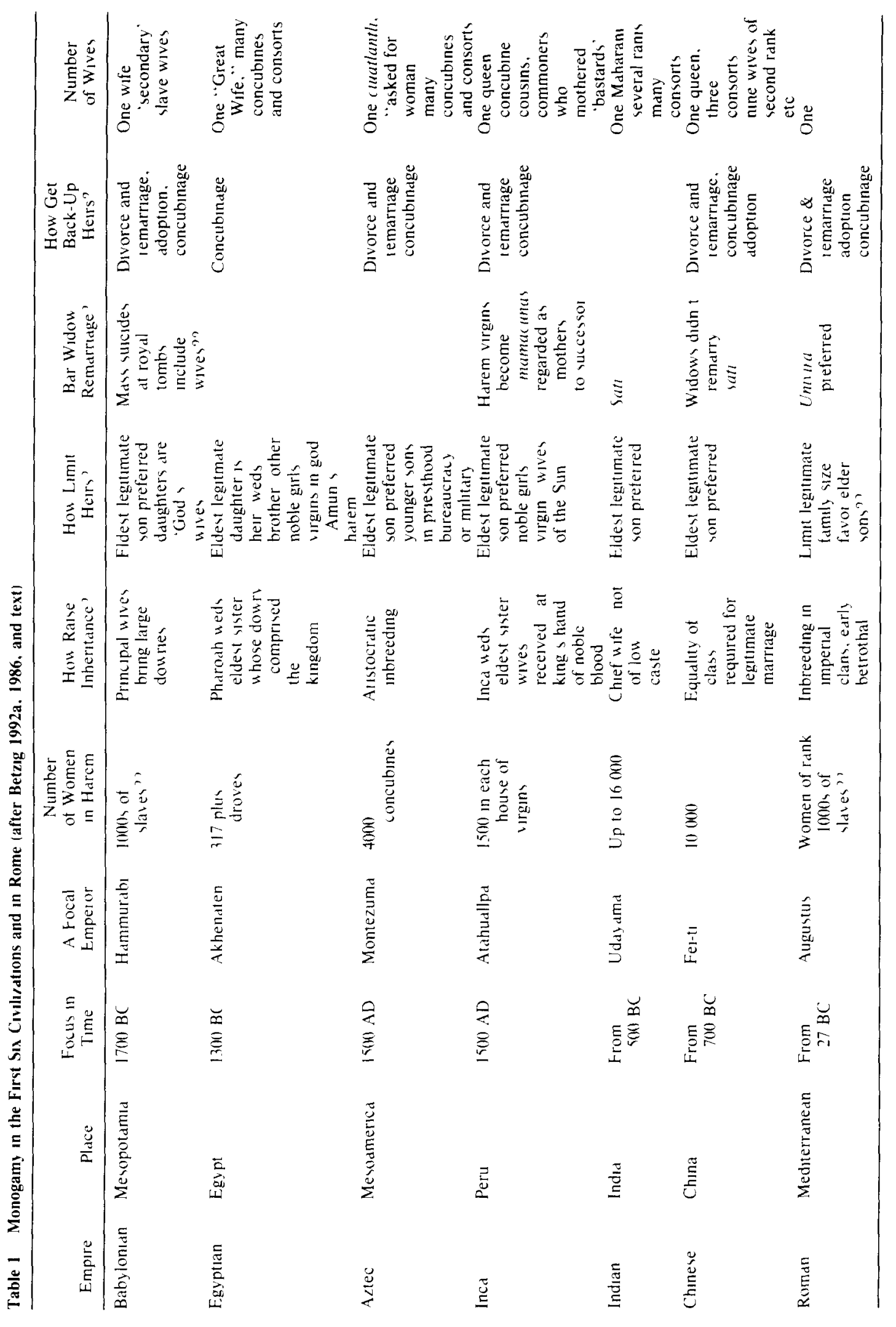


marriage in law and practice in order to answer that question I look first at limits on claims to an estate-at primogeniture, patrilıny, and monogamy. I look next at law and practice on adultery I look third at the raising of inheritance by marriage - at infant betrothal and incest Last, 1 look at law and practice on raising back-up heırs-at concubinage, adoption, and d1vorce

\section{THE LEX JULIA DE MARITANDIS ORDINIBUS AND THE LEX PAPIA POPPAEA: AUGUSTUS ON PRIMOGENITURE AND PATRILINY}

Wherever there is a lot of wealth to be passed on, it tends to get passed to the eldest son. Primogeniture and patrilıny - ceding estates to first-born sons-were the rule in the first six civilizations, in later states, and in medieval and early modern Europe (e g , Betzıg 1992a, Duby 1980, Stone 1977) All_or most —of a family's wealth was funneled into a single vessel Just one son-the eldest-would take a legitımate wife and sire legitımate heirs As a result the lineage-and its land-would last from generation to generation Why, then, was primogeniture absent in imperial Rome? I thınk the evidence suggests rich Romans did what they could to practice it, and Roman emperors, from Augustus on, did what they could to prevent it (see too, e g , Crook 1967 104, 132, Brunt 1971 562-566, Champlin 1991. 183)

They were anticipated by centuries of precedents As early as the fifth century $\mathrm{BC}$, the Twelve Tables mandated that intestate Romans leave their estates equally to all legit!mate sons-and daughters Romans could disınherit sons by will as long as each was specifically named But fallure to disınherit in the proper manner made wills void, as a result, rules of intestacy held, and every legitımate son and daughter would get an equal share (Crook 1986. 59-65) In AD 26, the lex Junia Vellaea extended that rule to grandsons (p 64) And entall was strictly illegal-no one could make unborn generations heirs (Crook 1967 122) After the second century AD, trusts set up to get around laws lıke these were declared ınvalıd (ın Hopkıns $1983 \quad 76 \mathrm{n}$ 57) John Crook asks. "What is at the back of all this' Well, it looks as if sweeping away all the male heirs (perhaps all but one, to achieve primogeniture by the backdoor and defeat partibility and splitting-up) was not thought very nice"' (1986. 65)

Cicero said "the censors are to prevent celibacy" (De Legibus, 111, in Kiefer 1934 34) Censors asked every citizen, "have you a wife for the purpose of breeding children?" By $403 \mathrm{BC}$, they may have made bachelors pay fines In $132 \mathrm{BC}, \mathrm{Q}$ Metellus Macedonıcus made a famous speech against Romans' reluctance to marry, he was a censor too And Julıus Caesar, in his land reform of $59 \mathrm{BC}$, gave priority to fathers of three children or more (see Brunt 1971 559; Rawson 1986. 9-11, Treggıarı 1991a: 57-9) In Augustus' own words, " 'it was never permitted to any man, even in olden 
tımes, to neglect marriage and the begettıng of children, but from the very outset, when the government was first established, strict laws were made regarding these matters " (Dio, History, Ivı 64 ) But he "Increased the penalties," the force and extent of Augustus' laws, the laws that began with imperial rule, are generally thought to be revolutionary As early as 29 BC, just two years after Actium, the new emperor put together laws opposed to bachelors and in favor of fathers, but vigorous opposition made him withdraw them (Frank 1975 43) Then in 18 BC, he introduced the lex Julia de martandis ordinibus, supplemented in AD 9 by the lex Papıa Poppaea Those laws stuck for centuries

Few direct quotes from Augustus' laws, or their embellishments by successors, survive Fragments exist in Gaius' Institutes, Justınıan's Digest, and a few other sources Their gist is that celibates of childbearing agemen from 25 to 60 , and women from 20 to 50 -were punished, while parents were privileged. Unmarried people were forbidden to take inheritances and legacies except from cognates to the sixth degree, married people without children could take half, married people with three children might come into the full bequest. Fathers of three children were preferred for promotion to provincial governorships, in standing for office, a man could subtract a year for each child from the mınımum age requirement, fathers were preferred to fill vacant public posts. Mothers of three chıldren were exempt from having a tutor, mothers could wear the stola instita, unmarried men were banned from public games, fathers took precedence in having the fasces carried before them, and married proconsuls could pick their provinces, priority dependıng on the number of theır chıldren (see, e g , Frank 1975, Csillag 1976, Treggian 1991a) Emperors rewarded delatores, or spies, on evaders And they granted exemptions Pliny the Younger's letters to the emperor Trajan are full of sycophantic attempts to get his infertile friends granted the privileges given fathers of three children (Letters, $\mathrm{x}$ )

By his own account, Augustus was trying to keep Rome's elite from dying out $\mathrm{He}$ was particularly incensed at "you, then, who are Romans from the begınnıng and claim as your ancestors the famous Marci, the Fabı, the Quintı, the Valerı, and the Julı, do you desire that your familes and names alıke shall perısh with you" " (Dio, History, Ivı 8 1) Some take hım at his word To Andrew Wallace-Hadrill, for instance, fathers of three children were, given Rome's high mortality rates, most likely to produce the single surviving heir on whom they could most conventently concentrate a patrimony (1981 59-61) The problem, I think, is that demographics are vicissitudinous Fathers who were lucky enough to rear two or more sons wanted the option of disınheritıng all but one

People have looked in vain for primogeniture in Rome There isn't any evidence of it. But there is abundant evidence of celibacy What nobody seems to have seen is that they amount to the same thing. To keep the majority from takıng legitımate wives and making legitımate heirs is to disinherit them, eventually Celibate sons' lines die out Only married sons' 
lines last The patrimony gets passed on, intact, to the married minority A man with just one married son, and no matter how many celibates, was a man who put primogeniture into practice

Again, the option to disinherit younger sons is one aristocrats have employed across empires to hold on to their estates This is what primogeniture is all about And this is the option Augustus closed-or tried to close-off Lots of evidence is consistent with this. If, for instance, the "moral" legislation was in the aristocracy's interests, they should have acquiesced But they did not. Suetonius refers to "open revolts" by the knights, they forced Augustus to amend, and even suspend, the lex Julta de martandis ordinıbus-although 27 years later the lex Papıa Poppaea may have been even severer, backed by a man who had been emperor for a full 36 years (Suetonius, Augustus, 34, Csillag 1976 32) Nor, if the "moral" legislation suited aristocratıc families, should fathers have tried to prevent their younger sons from gettıng married But they did According to the jurist Marcianus, in a passage from the Digest, "In the thirty-fifth chapter of the Julian Law those who wrongfully prevent the children whom they have in their power from marrying . are compelled through the proconsuls and governors of provinces to give them in marriage" (Digest 23.2 19, translated in Treggiarı 1991a 65) Clauses in wills leaving legacies sub conditione caelibatus, on conditıon of celıbacy, were cancelled (Csillag 1976 88-92)

Lots more evidence suggests men did what they could to favor a single son. Elder sons may have fared better in succession to high office Only a quarter of elite consuls of 249-280 BC had more than one consular or known praetorian son, while in the early empıre just 8 of 160 ordınary consuls, and not one of 233 suffect consuls, had more than one consular son Keith Hopkıns attributes that, in part, to "the bias against a second son of the same father attainıng high political office", (1983 105, see also pp 65-66) Every emperor with more than two sons left Rome to the first (Corbicr 1991c 185) A father's first name went to his male first born, and even eulogies in Rome were delivered by eldest sons (Hopkıns 1983 201)

More direct evidence that younger sons were given less than equal shares is that their parents tried to find livelihoods for them The younger Plıny complatned to a friend that when second children were born, fathers were forced to look for rich in-laws (e g, Letters, i 14) Rich mates might be sought for all sons, unigeniture would make it more important for the latter-born

The classic alternative - to let younger sons fend for themselves in war, administration (secular or religious), or commerce-was common Most men in the equestrian order-the bachelor knights who filled Augustus' Forum-made their own living at moncy-lending, land-leasing, or trade, "big merchants and plutocrats were mainly recruited from their ranks" (Csillag 1976 61) Many of these men were younger sons As Susan Treggları says, "senators were distınguished from the next order, that of the equites, by their constitutional functions But socially the two groups were closely linked " Father and son, or brothers, commonly came from different orders 
(1991b 92) Interestıngly, the fact that men in command of regıments were called "young So-and-so," regardless of age (Veyne 1987 105), also suggests some were younger sons-before the fashıon of medıeval knights, celıbate latter-born sons plagued with the label "junior" (e g, Duby 1983) In spite of all the legislation, the number of bachelors in Rome started out large, and grew Celibacy in the aristocracy increased in the last centuries of the republic, celıbates seem to have outnumbered married men by AD 9 (Csillag 1976 43, Dio, History, Ivi 12 2) Finally, as the empire wore on. more and more younger sons ended up in the church Peter Brown writes, "quite wellto-do village and urban families dedicated their children to the service of God, as often as not to keep the family heritage together, unburdened by excessive sons" (1987 293) Though the provincial church was chronically short of recruits, childhood celibates were common among the rich in Rome (Brown 1988 357) Late in the third century, and especially after Constantine from the fourth century on, celıbacy increased dramatıcally in the great Roman families (Etıenne 1978, Drijvers 1987) These kinds of disınheritance later paralleled the "three estates" in medieval Europe (e g, Duby 1980 , Boone 1986), and they were standard practice in other aristocracies, includıng nobılıtıes as remote as Aztec Mexıco and dynastıc Egypt (e g , Padden 1961 21, Redford 1984 14)

The most direct evidence of primogeniture in practice should come from Roman wills Although no complete Roman will exists in its original form from before the fourth century $\mathrm{AD}$, and though the complete contents of only a handful survive, Edward Champlin has collected fragments of evidence on inheritance from hundreds of literary, legal, and inscriptional sources (1991 29-40) The testators referred to in these fragments were an elite group most empire inhabitants were noncitizens, so will-less, by law, most testators were landowners, many were rıch (pp 42,54) But, accordıng to Champlın, "there is no hint of customary primogeniture in Roman testaments" (p 111) Why not' I think the answer is, if younger sons were kept from gettng marred, and so from getting legitmate heirs, explicit dismheritance may have been unnecessary The shares of family estates left to celibate sons should have been bequeathed, in the end. to elder brothers and their heirs As Champlin says, "the relatives most frequently named as heırs or legatees are brothers "Nephews are also commonly named ( $p$ 127)

Last, Romans went so far as to keep their freedmen from marrying, and Roman emperors tried to make them marry According to Csillag. "it often occurred that the patronus on the occasion of the mamumisso made the libertus or liberta take a solemn vow that they would not marry." the lex Julia de maritandis ordinibus decreed that those vows were not binding (1976 89-90) Freed slaves had obligations to their patrons, among them obsequium, or respect, operae, or a fixed number of days of work, and rights of succession on death (e $\mathrm{g}$, Watson 1987 35) Accordıng to a passage in Justınian's Codex, the lex Jula de maritandis ordinibus exempted freedmen with two children of operae, though freedwomen were exempt only if they'd 
married with the consent of their patron (In Csillag 1976 169; Watson 1987 42) Even more important, accordıng to Galus' Institutes, patrons of freedmen and freedwomen with a child could claim only half their estates, patrons of freedmen and women with two children could claim just a third; and three children excluded a patron's claums altogether (Brunt 1971. 565, Csillag 1976 157-158) Why should Augustus have encouraged freed slaves to reproduce? Maybe in order to disperse their estates as well These laws targeted the rich-freeborn men and women with property and, specifically, freed slaves worth 100,000 sesterces or more (e g , Brunt 1971 561, 565) Some freedmen were "proverbıally" rıch-Petronıus' Trımalchıo amassed "estates it'd take a kite to fly over" and was "worth millıons of millıons," and a freed Metellus left 7,200 oxen, 257,000 other anımals, 4,116 slaves, and 60 millıon sesterces (Petronius, Satyricon, 15 37, Pliny, Natural History, 33 134) Many freedmen were descended from, and many fathered, the Roman aristocracy (e.g , Betzig, this volume) Many freedmen might, in fact, have been younger sons

Several facts give the lie to the argument that Augustus was after an increase in the citizen population For one thing, at the same time that he offered incentives to rich freedmen to bear children, the lex Fufia Caninia of $2 \mathrm{BC}$ and the lex Aella Sentia of $\mathrm{AD} 4$ set limits on how many slaves a man could free, and how (e $g$, Westermann 1955 89) For another, the law let the poor-freeborn and freed-alone, some soldiers were even prohibited marriage (Brunt 1971 562, Dixon 1992 55) And for another, fathers were the targets of many rewards, efforts to raise birthrates elsewhere have focused on mothers (see Dixon 1988 73). Besides, there was hypocrisy involved M Papıus Mutılus and Q Poppaeus Sabınus, the consuls who sponsored the lex Papata Poppaea, were bachelors, Augustus hımself, of course, was the father of a single legitımate daughter

I should add that, like aristocratic younger sons in the Middle Ages, and in other ages, Roman knights and monks weren't always chaste (cf Betzig 1992a, 1993a) Anthony and the earliest ascetıcs were obsessed with sex, more comfortable monks, centuries later, might have lived those fantasies out According to Alıne Rousselle, even under the secular empire, monks got women with children "This was such a common occurrence that pregnant girls who did not want to betray their real lovers falsely accused the anchorites " As an abbot from Alexandria put it, if you weren't thinkıng about it, you were doing it (Rouselle 1988 144, 150, cf Duby 1978, Brundage 1987, Bet7ig 1992c) Knights were at least as notorious The emperor Claudius told one, a "seducer of girls and married women," to restrain his passions, Augustus, with the help of ten senators, "cross-examıned every knight on his personal affairs" and penalized the most scandalous, and in his famous speech in the Forum, he had them up for "wantonness and licentıousness" an exceedıngly common accusation (Suetonıus, Claudıs, 16, Augustus, 39, Dio, History, lvı 7 1)

But agan, none of this mattered as far as the law was concerned The 
"moral" legislation was indifferent to bastards Its concern was with heirs Its ostensible point was not to maximıze the production of illegitımate children; the point was to maximıze claims to aristocratic estates

So much for primogeniture When Romans could pull it off, it effectively cut the field of heirs to one Two other strategies narrowed the field considerably One was patrilıny Patrilıny, of course, halves the field of heirs Aristocrats have left estates to sons, and excluded daughters, across polygynous cultures (Dickemann 1979a, Hartung 1982; Betzig 1991) Inheritance in Rome, from the time of the Twelve Tables, is supposed to have been bilateral-passed on to sons and daughters Why was patrilıny absent in the Roman empire? Again, I think the evidence suggests rich Romans did what they could to practice it, and Roman emperors did what they could to prevent it

The Twelve Tables said the estates of Romans without wills should be split up equally among male and female children-though sons had to be disınherited specifically by name, and daughters could be lumped in a single clause (e g , Crook 1986 64) Even earlier, the leges Reglae, or "royal laws" supposedly codified by Rome's last king, required that Roman fathers rear their first-born daughters-suggesting some were reluctant to do that (e g , Hallett 1984 21, 123) Under the empire, the "moral" laws contınued to sabotage patrilıny According to the Gnomon of the Idiologus, a set of administrative rules started under Augustus, free Roman women worth 20,000 or more were taxed at one per cent per year as long as they remained unmarried, and inheritances left to women worth 50,000 sesterces or more were confiscated if those women lacked husbands and children (In Treggiarı 1991a 78) Fathers were restrained from barning the marriage of daughters, like sons, Marcianus' passage in the Digest compelled fathers to let their children marry, irrespective of sex (Digest 232 19, translated in Treggian 1991a 65) Other passages in the Digest suggest that by the time of Augustus it was obligatory that fathers provide daughters with dowries (e g, Csillag 1976 45, 93-95)

But Romans seem to have done what they could to favor sons Male bias anticipated inheritance Boys were favored over girls from birth, or even earlier-boys were better "cooked" in the womb, Dionysius of HalIcarnassus said parents hoped for the birth of a son more than for a daughter, Plutarch sald mothers had "greater love for their sons"- though daddies preferred their daughters (Brown 1987 243, Eyben 1991 119) Though numbers are hard to come by, it is commonly agreed that little girls were more often killed and abandoned than little boys In the epitaphs, or inscriptions, males consistently outnumber females on the order of two to one that holds for three elite families, for homeborn slaves or vernae, for foster children or alumni, for children commemorated in a sample of 16,106 from Italy, and for adults and children commemorated in a sample of nearly 55,000 from the whole Roman empire (Treggiarı 1975, Rawson 1986, Hopkıns 1983. 225, Shaw 1991) Some of the bias might mean nothıng but selectıve commem- 
oration-men and boys might have been more inclined to leave their names in stone (Hopkıns 1966). But literary sources suggest female infantıcide accounted for some of the bias-though it's impossible to tell how much (e g , Pomeroy 1975, Harris 1982, Oldenziel 1987). And literary sources suggest, too, that girls were abandoned more often; if John Boswell is right that as many as $40 \%$ of city-born babies were abandoned, the number could have been high (1988. 135) The fact that well-to-do Romans differentıated among sons by giving them their father's nomen, plus his hereditary cognomen, plus a first name or praenomen, while daughters of the classical aristocracy got nothing but a feminıne form of the nomen and had to be differentiated by adjectives like major (elder) and minor (younger), suggests that few of the best families reared more than one girl (Hallett 1984 77-80). Dio, in the context of Augustus' laws, complained that "there were far more males than females" among Roman nobles (History, liv 16 2)

Once parents had decided to bring them up, rich boys may have fared better than girls in several respects Keith Bradley, for instance, found 97 inscriptions listıng pedagogues and their charges, 32 were assigned girls and 62 boys, though the last is an underestimate since some inscriptions refer to an unspecified number of sons (1991a $48,66 \mathrm{n} 36)$ Only rich boys went to school past the age of twelve (e g., Veyne 1987 19) At twelve, girls could be legally married (e g., Gardner 1986) Girls of the highest orders-in senators' or emperors' familıes-sometımes married even earlıer (e g , Treggiarı 1991b), girls in society at large married late in their teens (Shaw 1987a) As Paul Veyne says, "in the end, it was the husband who completed the education of a young woman of good family" (1987 20), or, as Ludwig Friedlander put it, "girls left the nursery for the married state" (1908, v 1 236) Boys married later. around twenty-two or -three in the senatorial orders, in their late twenties in society at large (Saller 1987, Syme 1987) So even before they came into an inheritance or dowry, sons seem likely to have been given more of what parents had to offer-like cash and direct care-than daughters

But the biggest difference was probably in inheritance According to Champlin, the laws of succession "were always more favorable to daughters than were the wishes of testators" (1991 119) In his sample, more than four out of five wills were written by men, he infers that they must have owned proportionately more property (pp. 46-47) "Sexual inequality in testation reflects incquality in inheritance" ( $p$ 49) Where both daughters and sons were heirs to an estate, sons came into a larger share Typically, a son might get half, and each of his sisters a quarter, or a son three-quarters and his sister the remainder, or a daughter a specific property and a son everythıng else ( $p$ 114) Often a daughter might get no more than her dowry Dowries could be substantial in Rome, but they were a small fraction of famıly fortunes (e g, Saller 1984) Champlin says they may have been small because they made up a daughter's portion (1991 117) "In Rome, a model 
of a patrilineal society , it was the father who passed on name, status, and patrimony" (Corbier 1991a 53)

Like younger sons, daughters might also be disınherited through celıbacy This was common in other empires as well (e g, Dickemann 1979a, Boone 1986, Betzig 1992a,c) With the exception of the six Vestal Virgins in Rome at any tıme, celibate women were "practıcally unexampled" in the rıchest classes late in the republıc and early empıre (Treggıan 1991a 83) That changed as Christianity spread By the third century, according to Peter Brown, girls were dedicated to the church in infancy-only to be "withdrawn by their families, in an equally high-handed fashion, when a better use could be found for them" (1988 261, see too Duby 1983) Ascetic women were expected to be of substantial means (Brown 1988 344) Though the first converts to Christianity were poor, by the third century women from the senatorial class were common converts Accordıng to Jan Dryvers, "senatorial women in Rome showed an increasing interest in a Christian life of virginity and asceticism from the middle of the fourth century on" (1987 242. see too McNamara 1983) Fathers and grandfathers of the first nuns were consuls and prefects descended from the old republican aristocracy (Drijvers 1987 246) Interestıng to add, like celibate sons who lived as monks or knights, celıbate women were not always chaste, that disgusted Cyprian of Carthage, St Jerome, and Tertullian at least (In McNamara 1983 116117. Drujvers 1987 249, Veyne 1987 12, cf Power 1922)

Given the consistent son bias in inheritance, some Roman law seems superfluous From the time of the Twelve lables, females had no right to leave an inheritance to sons or daughters, later the lex Voconia of $169 \mathrm{BC}$ barred people in the richest property class, worth 100,000 sesterces at least, from naming women as heirs - though effects of these laws were softened by praetor's edicts in favor of equitable settlements late in the first century $\mathrm{BC}$, and by the senatusconsulta Tertullianum and Orfitianum easing the transmission of property between mothers and children in the second century AD Under the lex Voconia women could take legacies, but never more than was left to the principal heir Romans got around the law by giving a fidelcommissum, or trust, to third party men who would in turn pass the estates on to women (Hallett 1984 90-96, Dixon 1985a, Saller 1991) Accordıng to John Crook, "agnation gave way to cognation" in time (1986 79)

Why' I thınk the answer might have somethıng to do with unigeniture If the object was to concentrate inheritance on a single heir, the best option would be to rear several sons in order $t o$ ensure a survivor, and then to disinherit the remainder That made the first born son the heir apparent, and latter born sons "contıngency heirs " When that option was closed by celibacy laws, second best was to limit fertility, and so raise a single surviving son But that was risky A father who reared fewer sons was less likely to end up with a male survivor (e g, Hopkins 1983) The way around that problem was to leave the estate to a daughter who could, in turn, pass it on to her own son Here daughters, rather than younger sons. were made "con- 
tıngency heirs " Patrilıny was sacrificed, for a generatıon, to unigeniture The estate was conserved, and in the end it went to a son

Plenty of evidence is consistent with this Will fragments suggest daughters were common heirs "In brief, sons before daughters, but daughters before everyone else," and literary sources from the late republic make it clear that children were expected to succeed to their mothers (Champlin 1991 120, Dixon 1988 53) Alternatively, a daughter's son, or a sister's son, might be made heir by adoption (e g , Corbier 1991a 67, cf Hallett 1984 109), this was tantamount to the same thing That is, whether the inheritance was left with the woman directly, or with her husband or son, it ended up in the same hands her son's Estates left with women were supposed to end up with men Some estates went to daughters' sons Daughters' husbands were often made heirs by adoption, ties were strengthened by the birth of a son (e $\mathrm{g}$, Hallett 1984) When bequests skıpped a generation. grandsons were greatly preferred to granddaughters (e g, Champlın 1991 114) Other estates ended up with nephews Judith Hallett refers to "the frequency with which we encounter well-born avuncult without sons who adopted their sisters' male issue," the elder and younger Plıny are a classic example (1984 163) As Champlın points out, nephews were often named heirs-next after brothers "Nieces, however, are never mentioned" (1991 127) The etymological overlap between the Latın terms avus, or grandfather, and avunculus, maternal uncle, may be consistent with this ties to both men would be strong if they were likely to grant an inheritance-through the intermediary of daughters or sisters who acted as "contıngency heirs" (see Hallett 1984 127f on etymology)

Two other trends are consistent with the shift from agnation-a stress on the male line, to cognation-a stress on both parents' kın One is the switch in emphasis, as Richard Saller points out, from familia to domus (1984b) Familia, as in the Twelve Tables, often refers to a patrimony, it concentrates on agnates Domus, on the other hand, literally refers to the "house," it takes in cognates as well (Saller 1984b 338, 342) As Garnsey and Saller say, the new emphasis on domus coincided with "an increased interest in daughters as perpetuators of the family" (1987 141) Again, I thınk that switch to cognation was against the first wishes of rich Romans, who were forced to use daughters, rather than younger sons, as contıngency heirs-because of the lex Papıa Poppaea and other celıbacy laws

The other trend that I think coincides with the shift to cognation is the switch toward marriage sine manu (e g, Balsdon 1962, Hopkıns 1983, Treggiarı 1991a) If daughters, rather than younger sons, were to be back-up heirs, it was essential that they be eligible to inherit That they were not under manus marriage, preponderant in the republic In manus marriage, a daughter was transferred to her husband's authority, gained the right to inherit along with his children, but lost rights to her father's patrimony in sine manu marriage, a daughter forfeited her right to inherit from her husband, but she retained her rights as her father's heiress "For reasons which 
are obscure," marriage changed form in the last two republican centuries (Hopkıns 1983 86, see too Treggiarı 1991a 34) If so, that change coincided with the censors' acts against celibacy, with the shrinking of the legitımate Roman family, and with increasing reliance on women to hold family property Again, I think Romans were forced by the celıbacy laws to make a choice, and unigeniture won over patrilıny When disınheritance was no longer an option-when all of their children were forced to marry legitımately and to have legitımate heirs-the Roman arıstocracy shrunk the size of their families in order to concentrate their patrimonies And when they were often left without sons as a result, daughters became heirs to their estates-for a generatıon, at least Contıngency heırshıp by daughters required that they inherit from their fathers Marriage sine manu let them do that

So much for patrilıny If unigeniture cut the field of heirs to one, after patrilıny cut the field in half, one last strategy was the first to narrow the field-monogamy A man might beget as many children as he lıked, but only legitımate children borne to his legitımate wife could come into his estate (Goody 1976 104-111) The most polygynous empures on earth, in terms of matıng, have been the most monogamous, in terms of marriage (Betzig 1992a) In the Roman empire, as in other empires, matıng made children, marrage made heirs Romans were explicit about it For instance, to Cicero a man with wives in two countries just confused the issue of his succession, to Soranus "women are usually married for the sake of children and succession, and not for mere enjoyment," and to Augustine sons and slaves were distinguished by the critical factor of heirship (Cicero, De Oratore, 1 183, Soranus, Gynaecology, 134. Augustine, City of God, xix 16, see Shaw 1987b 11 19-20,36-37) The term matrona conferred the legal right to bear a man's heirs (Hallett 1984 216)

Rich Romans who married at all kept their familıes small Peasants might have been more prolıfic, Tacitus propagandistically approved of Germans who thought it "wicked" to restrict the number of their children (Germania, 19) Again, the trend toward infertility in the Roman arıstocracy seems to have corresponded with celibacy sanctions The Roman aristocracy limited fertılity from the last century BC or before (Hopkıns 1983 78) As Treggiarı says, family inscriptions from around then seldom include more than a few children, legal texts rarely mention guardianship of more than one or two children, and literary sources suggest it was typical to leave one, two, or three grown children (199la 404-5)

This was of course, in Jack Goody's words, just another "strategy of heırshıp" (Goody 1973) Fertılity lımıtatıon dıdn't necessarıly reflect a lack of interest in reproduction Plenty of rich Roman men had sex with women other than their wives, and may have gotten many chıldren by them (Betzig, this volume) Fertility limitation-by wives-reflected an interest in wealth People-from Polybius to Augustıne-were quite explicit about it Under the Severı, abortion, infanticide, and exposure began to be regarded as "tan- 
tamount to murder," and were eventually punished (Gardner $1986155-$ 159)

\section{THE LEX JULIA DE ADULTERIIS: AUGUSTUS ON ADULTERY}

Rich men in Rome, then, lıke rich men in other places and tımes, made an effort to funnel wealth onto a single heir They also did what they could to make sure that heir was a relatıve They wanted to be both pater and genttor to their sons and daughters Though many were happy to father bastards, none were happy to have bastards fathered upon them This theme cuts, of course, across cultures as well, it has been called a "Mediterranean" pattern (e g, Cohen 1991 112), but it's more ecumenical than that Fathers surest of their paternity have given more to their children, fathers with the most ınheritance to offer have been most circumspect about ınfidelıty (e g , Gaulın and Schlegel 1980, Dickemann 1981, Flınn 1981, Hartung 1985, Daly and Wilson 1988) Why, then, did Augustus find it necessary to impose public sanctions aganst adultery? I think he raised the risk of adultery by making it a public, rather than a private, crime (see too Cantarella 1991, Cohen 1991) He raised the risk that nonrelatives would inherit in another way, as well He insisted that widows-who were, and always had been, eulogized for fidelity to dead husbands-remarry Remarried widows were at risk, of course, of leaving their own and their husband's wealth to children by second husbands

In Romulus' Rome, according to Dionysius of IIalıcarnassus, an unfaithful wife should be killed by her husband and his, or her, kin Cato's classic double standard statement is consistent, he's supposed to have said, "If you took your wife in adultery, you might kill her with impunity without trial, but if you committed adultery or were adulterated, she would not dare to lay a finger on you, nor has she the right to do so" (Aulus Gellıus, Noctes Atticae, x 23 5, translated in Treggiarı 1991a 269) Other husbands, in Plautus and other writers, bcat or castrate their wives' lovers, though actual killings of wives or their lovers are conspicuously absent in Roman writıng It isn't clear what a husband could, or could not, do to an adulterous wife before Rome became an empire But as Treggiarı says, "the regulations of the Augustan Law suggest a society in which it was accepted as natural that either a woman's father or her husband might attempt to kill her in the heat of the moment," and her lover too (p 274)

Augustus' adultery laws are supposed to have wiped out several precedents, but it is unclear what they were As early as the fourth century BC aedıles may have prosecuted men for seducing married women, censors might also have interfered (Treggiarı 1991a 275-277) Stıll Augustus' lawthe lex Julta de adulteris of $18 \mathrm{BC}$-was, again, apparently "revolutionary " It was the first surviving Roman legislation addressed to infidelity, and it 
ran contrary to the republican norm that the state should stay out of its citızens' homes (see Cohen 1991 110. Treggiarı 1991a 293) Fragments from at least five of the nıne chapters of the lex Julla de adulterils survive

According to the second chapter, a father had the right to kill his daughter's lover-provided they were caught in the act, in lis own or in his sonin-law's house, and that he kill his daughter at the same tıme According to the jurist Papinian, most of that law reiterated a right older than the Roman republic, "the novelty was in ordaining that both should be kılled" (Treggiarı 1991a 283) As Jane Gardner points out, "the requirement to kill both was lıkely to be a deterrent to killıng either," that "may have been Augustus" intention" (1986 130)

A husband was much more constrained In the first place, according to the Digest, while the father could kill an adulterer regardless of his statushe might even kill an ex-consul--a husband could just kill pimps, actors. gladiators, condemned men, famıly freedmen, and slaves As Treggiarı points out. "calculations about the status of the adulterer would be difficult to make in the heat of the moment" (1991a 284) The kıllıng was to be reported to the magistrate within three days, the status of the adulterer and the fact of adultery proved, in order for the husband to be cleared of homIcide Even more to the point, a husband could not legally kill his adulterous wife-though he might get off with hard labor or relegation, instead of death, if he did A man who caught, but did not divorce, an adulterous wife could be charged with pandering if he let her lover go And a man who had killed his wife's lover was compelled to divorce his wife at once He could prosecute her for adultery withın sixty days, but not without divorcing her first According to Ulpian, the Digest jurist, "as long as marrage lasts a woman cannot be accused of adultery" (Digest. 4851828 , translated in Treggiarı 1991a 286) If a husband falled to sue his guilty wife, anybody else could for the next four months As Csillag put it, the emperor "wanted to give great publicity to procedure aganst sexual offenders" (1976 193) Penalties were large adulterer and adulteress were relegated to different islands, half of his property, and a third of her property and half of her dowry, were confiscated Both suffered infama and lost their right to testify in court, convicted women could not marry freeborn men. and lost part of their right to inherit Panderers were subject to the same pendttes as adulterers Again, many of these penaltıes targeted the rich, as Gardner points out, loss of property, inheritance, and the right to marry free citizens would most likely effect those in the upper class (1986 128-131)

In accounting for himself, Augustus wrote that he was keeping Rome's morals clean (Res Gestae, vill 5) Some scholars are more or less sympathetic To Hugh Last, for instance, this lex Jula was "an outstanding piece of legislation," the beginning of the end of hedonic individualısm, by bringing the family under the state's protection (1934 447) More recently, to Richard Frank it was "part of an ideology designed to dffirm the traditions of the gentry and soldiers reared in the hinterland of Italy," from whom Augustus 
armies were drawn (1975 50), to Leo Radista it represented a reactionary regime's response to its subjects' "yearning for regeneration and cleanl1ness" (1980 288), to Karl Galınsky it tried "to make the rulıng classes of Rome and Italy into a morally superior and better people," the better to civilize, read imperialize, the rest of the Mediterranean world (1981 134) But again, Augustus' contemporaries were not always enthusiastic Martial and Juvenal made fun of the laws when Domitian revived them-"all/The while he himself was floutıng the law-and spiced/His crime with a dash of incest, in the proper tragic tradition"' (Satires, I1 29-33, cf Eptgrams, vi 2, $4,7,22,45,91)$ Others were evasive Suetonıus says well-born wives registered as prostitutes to commit adultery legally (Tiberius, 35), that loophole was closed by senatorial decree in AD 19 (Treggiarı 1991a 297) There were plenty of prosecutions

I thınk the evidence suggests Roman men were, and always had been, enormously concerned with fidelity in their wives, these laws were more likely to inhibit than help an injured husband Mediterranean men-and men everywhere else, for that matter-had always had a penchant to get revenge on their own That is borne out, David Cohen suggests, by the homicide cases against husbands reported in the Digest, and by literary tales of adulterers whipped, castrated, buggered, and killed at the hands of offended husbands (1991 118) As Cohen puts it, "If the primary purpose of the law was to strike fear into the hearts of prospective adulterers, why did it sharply limit the greatest dangers they could incur?" (1991 123) Eva Cantarella comes to the same conclusion So did the Digest jurist, Ulpian "It is granted to the father and not to the husband to kill the woman and any adulterer, because the heat and violent impulse of a husband readıly makıng a judgment was to be restrained" (Digest, 485234 , translated in Cantarella (1991 233) As Cantarella, citıng generations of Italıans, points out, husbands didn't dare put the matter to the courts "for fear of the perpetual infamy that would be their lot" (p 239) Men in the Roman empire, as in other empires, wanted very much to leave their estates to first-born sons related by blood (cf Betzig 1992a) Augustus and other emperors made it more difficult to do that

In Roman women, as in so many other women, no virtue was greater than chastity (cf, e g, Broude and Greene 1976, Dickemann 1981, Buss 1992) Virgın brıdes were preferred (e g , Treggıarı 1991a 105-107) Martıal, typically misogynistic, said he'd searched Rome for a girl who'd say "no" and found none, but then conceded there were thousands of virgins in town (Eptgrams, iv 71) Soranus, the doctor, called a long section of his Gynecology "Whether permanent virgınity is healthful," and another "Up to what time females should be kept virgins," he answered "yes," and around fourteen when menstruation began-and women were usually married (Gynecology, 17-8) Plutarch and others were explicit about that Romans "gave their maidens in marriage when they were twelve years old, or even younger In this way more than any other, it was thought, both their bodies and their 
dispositions would be pure and undefiled when their husbands took control" (Moralia, 138E, translated in Rouselle 1988 74, see too Hopkins 1965b) Fortuna Virgınalis, or Virgo, was the patronness of women comıng of age (Pomeroy 1975 206)

After they were married, Roman men kept a watch on their wives Roman matrons are occasionally thought to have enjoyed quite a lot of freedom Cornelıus Nepos was shocked that "no Roman thinks it an embarrassment to take his wife to a dinner party," wives at home in Greece spent all their tıme in "The Women's Quarter, which is never entered by a man unless he is a very close relation" (Vitae. vi, translated in Balsdon 1962 201, cf Wallace-Hadrill 1988) But Roman women were probably "not so free" in many ways (cf Gratwick 1984) Like matrons in other empires. they were often well covered, well attended. and even confined (e g, Dickemann 1981, Bet $\angle 1 g$ 1986. 1992a,c)

Brides spent the night before their nuptials "imprisoned in a crimson net," they were married in a long tumic, an orange veıl, and a metal colldr (Carcopıno 1940 81) A Roman matron from then on was often robed from head to toe, her palla might cover her head, her full-length stola was "a sign of her exalted rank" (Balsdon 1962 252, plate 2, (arcopino 1940 169) Exalted matrons abroad would be aloft Suetonius refers to the "closed sedan-chair of the sort used by women," and Juvenal describes wives and mistresses "in a grotto-like sedan, blinds drawn" (Suetonius, Otho. 6, Juvenal, Sattres, iv 19-20) They were surrounded by attendants, including the custos disliked by erotic poets, Veyne says 'this mobile prison which followed a woman everywhere, was the Roman equivalent of the gynecaeum" (1987 73, ef Patlagean 1987 573) In the republic, the praetolian edict de adtemptata pudictia- "concerning attempts upon chastity" made possible an action for injury aganst men who addressed virgins or matrons, took away their escorts, or followed them about (In Gardner 1986 117) Should the assault end in rape, in Rome as elsewhere. the insult extended to the woman's husband, her father, and even her husband s tather (In Treggiarı 1991d 309. of Thornhill and Thornhill 1990d,b) Some women seldom went out at all Plautıanus, Severus" notorious prefect. was the "most sensual of men," but refused to let hrs wite see or be seen by anyone (Dio, Historv, Ixxv1 157 )

Even when women stayed in, they were never alone As Veyne goes on. "the omnipresence of slaves was tantamount to constant survellance," well-to-do women were attended every waking, and even sleepıng, minute (1987 73) Inscriptions suggest most attendants were other women. though Livia's house included at least half a dozen c ubu ularu, men meant to guard bedchambers and refuse admittance to others (Treggidrı 1975 52.1976. 1987 12) Some might have been castrates That operation is supposed to have been big business early in the empire, and to have swelled enormously by its end (e g, Boswell 1988 113. I Iopkıns 1978) There are plenty of literary 
references to eunuchs Juvenal, Martial, and Ovid mention them (e g., Satures, v1 365-79; Epıgrams, 111 58, Amores, 11 2-3), Dio says Severus' prefect had a hundred free Romans castrated to walt on his daughter (History, Ixxvi 14 4-5), later in the empire, "hoardes" of eunuchs cleared noble women's ways (Hopkıns 1978 194)

Imperial legislation against castration might, then, have cut back-or tried to cut back on the supply of guards. At the end of the first century, Domitian "strictly prohibited" castration, takıng half the property of masters who castrated their slaves, and controlling the price of what castrates remained (Suetonıus, Domitıan, 7, Dıo, History, Ixvı1 2 3) Nerva, and later Hadrian in the second century, had volunteer castrates, masters or slaves who volunteered others for castration, and the doctors who castrated them killed, and their property confiscated by the treasury (Dio, History, Ixvilı 24 , Digest, 48842 , see Watson 1987 123) And Aurclian, in the third century, limited the possession of eunuchs to men of senatorial rank (Scriptores Historiae Augustae, Delfied Aurelian, xlix 8) If eunuchs in Rome, as in other empires, were meant to guard women against infidelity-on their own inıtiatıve or others'-then Roman emperors were, once again, actıng to lower the odds that a man would sire his own heirs

Chastity was the feminıne ideal Ovid was ironic "A wife must fear her lord, a prisoner's life/Is lawful, right, and proper for a wife" (Ars Amatorıa, 111 613-614), Jerome was eulogistıc "Pudicıtıa must be kept, for when it is lost all virtue collapses This is the chief virtue in women This recommends a poor woman, extols a rich one, redeems an ugly one, adorns a lovely one " (Adversus Iov'lnianum, 149, translated in Tregglarl 1991a 219) A good wife was morlgera, subservient to her husband, a good widow was univira, committed to a dead one In Roman writıng, wives are praised for solus, or fidelity to one husband, obsequentem, or obedience to that husband, and sempiternum, or eternal commitment to one marriage bond (Willams 1958) On Roman coins, women are remembered for pietas (devotion or piety), fides (fidelity), and pudıcitia (chastıty) (e g , Pomeroy 1975 184-185) And in the inscriptions, wives are eulogized for "old-fashioned" qualitıes, "the resemblance of children to their father" is stressed (Lattımore 1942 277, 300) Augustus himself, chastısing the knights in the Forum, asked "For is there anythıng better than a wife who is chaste"" (Dio, History, IV1 3 3)

A few well-known women were not Augustus exiled Juha, his only legitımate offspring, for infidelity to the island of Pandateria and then to Rhegium (Tacitus, Annals, 153, i1 24), she'd had fun drinkıng in the Forum with lots of lovers (Dio, History, Iv 10 12-5), eventually she died "from general debility and starvation" after Tiberius, the ex-husband she'd always looked down on, had her put under lock and key (Dio, History, Ivil 181 ) Claudius' wife, Messalına, was more vicious, one day, when the emperor was away, she and her lover Silıus, a consul designate, took vows made 
sacrifices broke bread and were marrıed, Claudıus, "soothed and a little fuddled," might actually have taken her back, but Narcissus his freedman made sure of her death (Tacitus, Annals, xı 26-38) And Faustına, Marcus Antonınus' wife, had a passion for gladiators (her son Commodus, Marcus' successor, was "born a gladiator"), she did in one lover, her son-in-law Verus, with a dish of oysters after he was stupid enough to confess to his wife, and once. when Marcus was sick, she proposed to a Syrian called Cassius "so that, if anythıng should happen to Antonınus, he might obtain both her and the imperial power" (SHA, Marcus Antoninus, xix, xxix, Verus, x, Dio, History, Ixxi 22) But these notorious women had another thing in common their dowry was, or approxımated, the Roman empıre Marcus was most explicit about it Reminded of various indiscretions, he responded, " "If we send our wife away, we must also return her dowry" And what was her dowry? the Empire, which he had inherited from his father-In-law" (SHA, Marcus Antoninus, xix 7-9) Everybody played by these rules Juvenal's sixth satire, an apotheosis of misogyny, sdys " she brought him three million In exchange he calls her chaste" (Sattres, vi 137) Martial had a horror of rich women, "Why have I no desire to marry riches'/Because, my friend. I want to wear the breeches" (Epigrams, vilı 12) Theophrastus might have put it best "It is difficult to support a poor wife, and torture to put up with a rich one" (in Jerome, Adversus Iovinanum, 147, translated in Treggiari 1991a 192) To the extent that a wife's riches raise his own, and his heir's, reproductive prospects, a husband might let her be promiscuous (cf Betzig 1992b) Seneca sand "chastity merely implies ugliness" (On Benefits, 111 16) "Chastity implies poverty"compared to a mate's-might be more accurate

Finally, how does all this relate to widow remarriage' The univia, the wife forever devoted to her husband, living or dead, was adored in Rome There are classic examples Condemned men often committed suicide, sometımes their wives joined them The younger Pliny tells the story of the famous Arria who took her life along with her husband, "with the immortal, almost divine words 'It does not hurt, Paetus' ' (Letter, 111 16) Tacitus says Arra's daughter, Thrasea's wife, wanted to follow her mother's example, but stayed alive for their own daughter's sake (Annals, xvi 33) Seneca's wife cut her own veins with his but revived (Tacitus, Annals, xv 63) The obvious parallel in India is satt, where widows threw themselves on their husbands' pyres, there are equivalents in other empires A less obvious parallel is getting put in a closster (e g, Dickemann 1979a; Betzig 1992a) Some Christuan Romans were "Orders of widows" were common from the first century, the first "convent" in Rome was in a rich widow's house, and by the Middle Ages cloistered widows-like closstered virgins-tended to come from the upper class (e g , Brown 1988 147-148. Drujvers 1987 24-28, Rouselle 1988 133) Powerful men have tried to keep ex-wives from findıng second husbands

What was the fear here? That an inheritance would end up in step- 
chıldren's hands Champlin finds that wives were left with larger legacies than husbands (1991 124) That makes sense if fathers were more likely to start second families A divorced or widowed father of the Roman upper class tended to choose a girl "at the height of her physical attractiveness" as a second wife, some of these men defrauded the fidelcommissum established on behalf of their children (Treggiarı 1991a 401, Saller 1991. 40, cf Buss 1992, Judge and Hrdy, this volume) But even women seldom got most of an estate from a dead spouse As Champlin writes, "in brief, and generally speakıng, wives were fondly remembered and their welfare carefully considered, but they were firmly separated from the bulk of the patrimony" (1991 124) According to Digest jurists, it was okay to leave property to a wife on condition that she not remarry (Digest, 351622 , in Saller 1991

42) Fathers-ın-law sometımes made sure they did not For instance Apuleıus' wife Pudentılla, was "the victım of virtual blackmaıl" by her husband's father, who swore he'd disinherit her sons if she wed anybody but her husband's brother Tiberius kept both Agrippina, his brother's son's widow, and Livilla, his widowed daughter-ın-law, from takıng second husbands for the same reason (Corbier 1991a 56) The elaborate procedures under which new widows gave birth suggest a related concern Among other things, a number of witnesses had to attend the birth, others had to be on guard outside to stop and search anyone entering, all entrances but one had to be boarded up, and at least three lights had to be on "for darkness is better adapted for the substitution of a child" (In Gardner 1986 52)

But Augustus made widow remarriage mandatory And he limited his prescription to women of childbearing age In fact, postmenopausal women were not allowed to remarry, since legal marriage took place "for the purpose of producing chıldren" (Rawson 1986 10) Stıpulations in wills making succession contingent on the celibacy of an ex-spouse had to be expunged (Csillag 1976 87) Under the lex Julıa, widows were punished unless remarried withın a year, the lex Papia Poppaea extended the period to two (e g , Treggiarı 199la 73) Widows who falled to remarry might lose their dowries to the treasury (e g , Csıllag 1976 94) Once again, "there was probably never an attempt to enforce this in the lower classes" (Rawson 1986 31) And, once again, the rich resisted (e g, Saller 1991 46)

\section{AUGUSTUS ON INCEST AND AGE AT MARRIAGE}

So Romans tried to make sure their heirs were their relatıves, and they tried to choose a single-legitımate, male, first-born-heir The third thing they did was try to raise his inheritance, and they did that, in part, by contractıng a proper marriage A proper wife should be, first, as well-connected as they were, that often meant she'd be a relative herself Inbreedıng, or even "incest," has kept assets withın arıstocratic families in many societies (e g , van den Berghe and Mesher 1980, Thornhill 1991, Betzig 1992a) It may have 
in Rome Second, a good wife should be rich, and she should bring a good dowry Competition for well-to-do husbands, and wives, has also been common across empıres (e g. Dickemann 1979a,b, Gaulın and Boster 1990, Betzig 1992a) It seems, too, to have been common in Rome Rich Romans often interbred with rich, well-endowed relatives, and in some ways Augustus and other emperors interfered

Matches could be made in infancy a good man. and a good woman. were hard to find Female infanticide. exposure, and disinheritance meant there were fewer avallable brides than grooms And elıte girls were. by definition, scarce So were elıte men So rich Romans sometımes betrothed their babies As Treggıarı says. "there are instances where great herresses or important dynastic partls were betrothed extremely young" (1984 422) Most examples come from imperial families Augustus' own daughter Julıa. the one he eventually exiled, was betrothed to Marc Antony's eldest son at the age of two (the boy was killed with his father's defeat as the triumvirate became a monarchy) Augustus' stepson Tiberius, who succeeded him, was betrothed to Marcus Agrippa's one-year-old daughter (that tie was dissolved so that Tiberius could marry Augustus' daughter and Agrippa s widow, Julia) (see Treggiarı 1984 422, Corbier 1991a. 62) But the law seems to have said again, do as I say, not as I do According to Suetonius, when Augustus found "that bachelors were gettıng betrothed to hittle girls, which meant postponing the responsibilities of fatherhood, he dedt with these evasions of the law by shortenıng the permissible period between betrothal and marriage" (Augustus, 34, see too Corbett 1930 1-23, Rawson 1986 21)

In order to get a rich spouse, Romans tried to choose young, and they tued to choose kın There has been some debate about how often close relatıves married in Rome After Jack Goody (1983) assumed inbreedıng was common. Saller and Shaw (1984) looked systematically at 33 couples in the senatorial aristocracy and falled to find a single case of patrilateral parallel cousin marriage, unions of brother' children were uncommon in their sample of inscriptions as well But there are many cases of "incest" in the imperial family Augustus gave Julid. his one legitımate child, thice husbands the first was his sister's son. Marcellus, the last was his stepson, Tiberius, only her second marriage, to Marcus Agrippa, bore frut (Sueton1us, Augustus, 63-64) Augustus gave his second stepson-who was arguably his own illegitimate son-to his sister's daughter. Antonid (Suetonius, Claudus 1) The issue of that marriage included the emperor Claudius. Julia Livilla the elder, and Germanicus Germanicus married Julid ' daughter, Augustus' granddaughter, Agrıppına the elder. from that unıon came nine children, the emperor Calıgula among them (Suetonuus, Augustus, 64, $7^{l}$ berlus, 54) Julia Livilla was married to the son of her father's brother, that is to Tiberius son. Drusus Claudius was married four times Messalınd, Claudius' third wife, was his second cousin. Agrippina the younger, his fourth wife, was his niece (Suetonius, Clatudus, 26). I could go on, this sort of inbreeding didn't end with the Julio-Claudian line There may be many 
instances of incest in the senatorial arıstocracy, too, when links through women as well as men are considered, and in-law as well as blood ties are taken into account (e g , Dixon 1985b, Corbier 1991b, Treggian 1991a 109_ 116) Brother-sister marriage was common in Roman Egypt, for reasons unknown (Hopkıns 1980)

Compared to canon laws of the Middle Ages, Roman law on incest was lenient (e g, Goody 1983, Brundage 1987) Unıons of kın hetween generations were not allowed-with the exception that, after Claudius wed his niece, the senate passed a decree permitting Romans to marry their brothers' daughters, a decree reversed half a century later under Nerva (Treggiarı 1991a 37-38, Dio, History, Ix1 318 , lxvı11 24 ) Untıl the third century BC, collaterals up to and including second cousins could not marry That rule "derived from custom, not law," and was first broken by a patrician By the first century BC, marriage between first cousins was allowed (Gardner 1986 35) In other respects, though, incest prohibitions were extended At the turn of the first century, in-laws were included, eventually, fictive kın were included as well (e g, Corbıer 1991b 134) As Pál Csillag says, "in the course of time, by the inclusion of the cognates, the notion of incest became even more comprehensive [and] in the course of time the notion of incest was expanded so as to include persons beyond the cognates, " 1 e , adoptive kın (1976 184) This makes it clear that the issue was not matıng but marriage, the problem was not one of concentratıng genes, but of concentratıng wealth This is made even clearer by the penalty imposed the issue of illegal marriages were illegitımate, $1 \mathrm{e}$, ineligible to inherit In addition, incestuous husbands or wives might be deported, relegated, or thrown from the Tarpeian rock (e g, Csillag 1976 199) It is surprising that the prohıbitions weren't extended even further

\section{AUGUSTUS ON CONCUBINAGE, ADOPTION, AND DIVORCE}

Onc set of marriage-or "hcirshıp" - strategies remains In case his rich, related wife falled to raise a single, related heir, a Roman husband tried the usual back-up tactics He might divorce his first, unfaithful or infertıle spouse, and then marry another, adopt an herr-often rich, and usually a relative, or give his estates to a child by a back-up wife, a woman who lived with hım farthfully but brought hım no dowry, a concubıne All of these tactics were in practice in other empires (e g , Goody 1973, 1976, 1983, Betzig 1989, 1992a), they seem to have been practiced in the Roman empire as well (e g , Corbier 1991a,b) Both concubinage and adoption are supposed to have increased with Augustus' legislation (e g, Tacitus, Annals, xv 20) But there is little evidence, in this case, that Roman emperors interfered

Divorce was free and easy in imperial Rome It may not always have been The "first divorce" on record is dated at $230 \mathrm{BC}$, when Spurius Car- 
vilius Ruga got rid of his otherwise faultless wife for fallıng to rear an heir (e g, Dixon 1985b 357, see too Corbett 1930) Roman marriage required no more than mutual consent to live as husband and wife, Roman divorce had never required anythıng more than unılateral intent, or even d third party's intent, in the case of the paterfamilias of either spouse (e g , Rawson 1986 32) Imperial Roman law takes remarriage for granted (e g, Humbert 1972) And anecdotes about divorce are frequent in imperial literature and biography, Seneca's complaint that women counted the years by husbands rather than consuls is notable (On Benefits, 111 16) More systematic counts seem to bear such impressions out Treggiarı finds 32 attested divorces between 100 and $38 \mathrm{BC}$ in the republican aristocracy, her guess is that the odds of divorce in the senatorial and equestrian class were about one in six (1991c 43-46) And Keith Bradley studied the marital histories of consuls from 80$50 \mathrm{BC}$, and estımated a remarriage rate of about 39 percent (199la,b) Syme, In his lifelong study of the Augustan aristocracy, found the more he knew about a man, the more wives he was likely to uncover (1986) According to Suetonius, Augustus made some effort to close the divorce and remarriage loophole When he found "that married men were frequently changing their wives," he responded "by limitıng the number of lawful divorces" (Augustus, 34)

Another way to get heirs in the absence of children was by adoption Peter Garnsey and Richard Saller suggest that Romans might adopt "to avord the possibility of being burdened with a reprobate natural son" (1987 144) That could be, but Corbier and others are probably right that it had more to do with succession (199la 63) Though it was legal in principle to adopt when a legitımate heir was already avalable, "ddoption seemed pointless, indeed even suspicious, when the main obligation of the head of the family, the transmission of name and possessions, was already assured" (Corbier 1991a 66, ef Crook 1967 112) Romans adopted men, in the absence of legitımate sons And they adopted kın The lınk was often through daughters daughters' husbands, and daughters' sons, were most often adopted Paternal grandsons might be as well, especially when the lınk between themthe son-had died As Corbier says, "adoption hy the grandfather (aul) was one of the most natural of all practices" (1991a 68,70) Less often, brothers' and sisters' children might be made heırs by adoption (Corbier 1991a 70, cf Champlın 1991 126-129) If Hopkıns' estımate, based on Goody's, is right, then around $20 \%$ of well-to-do Romans might have ended up without a grown son, and another $20 \%$ might have had only grown daughters, there should have been plenty of room for adoption as an heirship strategy (Hopkıns 1983 100, Goody 1973) Emperors seem to have had little to say on the subject

They said more about a third contıngency strategy, concubındge As Saller points out, Roman concubines were used to limit the number of a man's heirs (1987b 73-75) Quite so it was an alternative to bigamy One legitımate wife made heirs, concubınes made stand-ins That's suggested 
by the fact that, as Crook points out, some tombs were put up for both a concubine and a wife, sometımes it's even "pretty certain that the women exercised their respective functions concurrently" (1967 102, but see Rawson 1974 288, Treggiarı 1981, Watson 1987 13) It's suggested in the Digest passage that says a wife could make her husband contract not to keep a concubine durıng their marriage (Digest, 451121 1, see Treggiarı 1991a 107) And it's suggested in Iuvenal, who says "Wives loathe a concubine's offspring/ to murder your stepson/Is an old-established tradition " $\mathrm{He}$ goes on "Trust none of the dishes at dinner /Those pies are steamıng-black with the poison Mummy put there" (Satıres, v1 626-632) Whether concubines and wives were kept serially or concurrently, the concubine's children tended to differ from wives' children in one overriding respect their mother lacked a dowry (e g, Gardner 1986 56, cf Daube 1969 102-115) But they were willıng and able to fill in as heirs By the process of adrogatı, legitimization, a man could bring under his potestas children of free status"his children, for example, by a concubıne," though more often a man chose an heir of his own class (Corbier 1991a 64) Even natural children by slave women might be made heirs by testamentary adoption (e $\mathrm{g}$, Treggiar1 1960, Wiedemann 1981, Champlin 1991) The lex Julia of 18 BC made it impossible for men of the senatorial class to take their freedwomen as wives (e g . Brunt 1971 145) That prohibition might have stood, to some extent. in the way of the legitımization of their children as heirs But people obviously got around it

\section{DISCUSSION}

I think the point of Augustus' moral legislation was to sabotage the arıstocracy $\mathrm{He}$ made it harder for a rich man to get a rich spouse, to keep her faithful, to leave his estate to a single son and, to a lesser extent, to choose a back-up heir Later Roman emperors stuck with those enactments, with modifications and additions, for more than three hundred years What was the result? In Csillag's opinion, "the historical aristocracy began to wither away The huge latıfundia disintegrated into parcels in the course of the proscrıptions" (1976 67, cf Hopkıns 1983, Garnsey and Saller 1987 145155) The alphas-Roman emperors, strengthened theır power by weakenıng the betas-the Roman aristocracy As Syme and others point out, that may have been done in many ways One of the most "intrusive and long-lastıng" must have been the "moral" legislation

Significantly, it all changed with Constantine's conversion In AD 320, the first Christian emperor repealed the Augustan legislation on caelibatus and orbitas, on celibacy and childlessness, both holy conditions under the new state religion (e g, Csillag 1976 204-207) He also restored the right to prosecute wives for adultery to the immediate family, making the husband's responsıbılity primary, calling husbands "the avenger of the marriage 
bed" In the Theodosian Code (e g , Cohen 1991 125, see too Cantarella 1991 234) And he abolished the law requiring that widows remarry, in fact, by the end of the fourth century widows had by law to yield rights to their first husbands' patrimonies if they remarried, to church fathers, remarriage banned women from the kingdon of heaven (e g , Saller 1991 46, Dixon 198850 , Csillag 1976 205)

At the same tıme, new penaltıes were introduced Most had to do with contıngency heirs Divorce by mutual consent was abolished. in the sixth century, by Justınıan (e g , Gardner 1986 89), in 326, accordıng to the Codex Justinianus, Constantıne ruled against keepıng a wife and concubine at the same time (e $g$, Treggiarı 1981 77) Laws passed by Christian emperors, and eventually by the church itself, prohibited divorce and remarriage, concubınage, and even adoption, and they vastly extended the "incest" prohibition (e g . Goody 1983)

I thınk a lot about that shift makes sense Imperidl Roman legislation pitted emperors against the aristocracy The point was to disperse their wealth and influence by lowerıng their inheritance That they did, most of all, by makıng them rear too many heirs They did it, too, by interfering with marriage strategies- with infant betrothal and "incest " And they did it by interfering with a man's right to punish his wife for adultery-raising the risk that his estate might end up outside the family entırely Incidentally, they made a lot of money, as penalties flowed into the treasury (e g. Wallace-Hadrill 1981)

Christian legislation, on the other hand, pitted church men against laymen The point here, as Jack Goody says, was to keep them from rearing heirs at all (Goody 1983) So the focus switched to interference with backup strategies people were free to limit heirs by primogeniture and patrilıny, but they were prevented from getting substitute heirs by adoption, concubinage, or divorce Why did Christianity condemn divorce and sanction celıbacy" Because, I thınk, men of the church were noble men's younger sons Conflict between families-emperors against the aristocracy, was superseded by conflict within the family-younger sons in the church against elder brothers who'd inherited their fathers' estates Men in the church who kept their elder brothers from rearing an heir might come into their estates by default-either indirectly, by their bequests to the church, or directly, by becoming back-up heirs themselves (Betzig 1992c)

What was the point of the conflict, in either case? Obviously, inherited wealth But why did that matter to anybody' Because it was, as it had always been, a means to reproduction That may seem a superfluous conclusion But I think it makes several pieces fall in place For one thing, it fits with the fact that men in Rome, and in the Middle Ages, as in other ages, seem to have had sexual access to as many women as they could afford, and arguably fathered bastards by them (see Betzig, this volume, on Rome, Betzig 1992c on the Middle Ages, reviews in Betzig 1988, Betzig and Weber 1992 on other ages) For other thrngs, it explanns why men rather than women 
should be preferred heirs, and why men should be so extraordınarily concerned with women's chastity

In this light, the whole point of monogamy must have been polygyny Even more ironically, the point of celibacy must have been polygyny, too Marriage rules exist to hold on to wealth, and men hold on to wealth to get access to women Across empires, the choice of a single, legitımate wife by the eldest, legitımate son has concentrated patrimonies, the consignment of younger sons, and many daughters, to celibacy has been the consequence of that strategy Few men in any aristocracy seem to have practiced chastity But most were probably celibate Most of them probably mated polygynously But just one man in each family married, and he married monogamously (e g , Betzig 1992a)

So it makes sense to choose one heir, but why must he be a son' The answer, as Robert Trivers and Dan Willard first suggested, may be that sons can be much more polygamous than daughters (1973, reviews in Trivers 1985, Hrdy 1987) A rich son might make hundreds of children, a rich daughter tens, so we expect, and find, polygyny to be common (e g , Murdock 1972, Low 1988, White 1988 on evidence, Bateman 1948, Trivers 1972, Clutton-Brock and Vincent 1991 on theory) If Darwin $(1859,1871)$ was right, and the evolved end of existence is reproduction, then rich parents should give their inheritance to sons (e g, Alexander 1974, Charnov 1982 for more theory) Daughters should inherit in sons' absence, so should sisters' and daughters' sons It fits that nephews and grandsons were commonly left an inheritance, and that granddaughters and nieces were not It fits, too, that more distant kin-on the order of first cousins and beyond-were generally left out (see Champlin 1991) As Willam Hamilton made explicit, if the evolved end of existence is the reproduction of genes, the means might include both direct reproduction and nepotısm (theory in Hamilton 1964 , reviews in Betzıg 1988, Betzıg and Lombardo 1992)

It may be more obvious why wives must be chaste It was to Juvenal, who warned Postumus, "marry a wife, and she'll make some flute-player/Or guitarist a father, not you" (Satires, vi 76-77) If the name of the game is the proliferation of one's own genes, then fidelity in a female matters where fathers care for their young (theory in Williams 1966 on levels of selection, Trivers 1972, Alexander and Borgia 1979 on confidence of paternity) Again, this pattern extends beyond the Mediterranean, fathers with an inheritance to offer are consistently concerned that their heirs share not just their names, but their genes (e g , Gaulın and Schlegel 1980, Dickemann 1981, Flinn 1981, Hartung 1985, Daly and Wilson 1988)

Secular Roman emperors passed laws to keep other men from punıshing philanderıng wives, and from leaving estates to first-born sons Christian Roman emperors, and later the church, did not 1 thınk the reason has to do with who was competing with whom Competition in the secular empire was between families between emperors and the aristocracy At best, competitors' estates were dispersed among many, female, unrelated heırs But 
competition in the Christian empire was n'thin famılies between younger sons in the church and elder sons in the "state" At best, a younger son might keep an older brother from rearıng an heir, and come into his estate by default But fallıng that, better the patrimony get passed to a single heir than to many, better to a nephew than to a niece, and better to a blood relatıve than to a stranger

Horace, admired hy Augustus, was right that the risk of civil war was raised by "immoral" acts "Sedition" at home meant peril abroad, and the cause of it all was a lack of morals "Teeming with sin, the times have sullied/First marriage, our children, our homes/Sprung from that source disaster has whelmed/Our fatherland and our people" (Odes, III 6) Or, even better, Metellus was right to say "the state cannot survive without numerous marriages" (Aulus Gellius, Noctes Attlcae, 16 6, translated in Galınsky 1981 131) The point of the moral laws was to preserve the emperor's peace on the emperor's terms That meant an end to infightıng among equals in the republican aristocracy, it meant the beginning of the imperial rule of one over many

I $m$ very happy to thank Suzanne Dixon for specific comments and general encouragement Thanks too to John Crook, the "Ogre of St John'," who writes "I think that all the main contentions of your paper are wrong,

\section{REFERENCES}

Alexander, R D The evolution of social behavior Annual Revien of Ecologvand Sistematics $5325-383,1974$

- and Borgid G On the origin and basis of the male-female phenomenon In Sexual Selectuon and Reproductwe Competition in Insects M Blum and N Blum (Eds) New York Academic Press. 1979

Augustine, Bishop of Hippo $C$ th of God, translated by Philip Levine Cambridge Harvard University Press 1966

Augustus Res Gestae Divi August introduction and commentary by P A Brunt and J M Moore London Oxford University Press, 1967

Balsdon J P and Dacre, V Roman Women London The Bodley Hedd, 1962

Bateman, A J Intrasexud selection in Drosophla Heredis 2 349-368, 1948

Betzig, L Despotism and Differential Reproduction A Daruiman View' of Histor, Hawthome NY Aldıne, 1986

- Matıng and parentıng in Darwinıan perspectıve In Human Reproductue Behauıu A Darwinian Perspectwe, L Betzig, M Borgerhoff Mulder, and P Turke (Eds ) Cambridge Cambridge University Press 1988

- Causes of conjugal dissolution a cross cultural study (ument Anthropologv 30 654-676 1989

- History In The Soctoblological Imagination, Mary Maxwell (Ed) Albany NY SUNY Press, 1991

- Sex, succession, and stratification in the first six civilizations In Socloeconomic Inequality and Soctal Stratification Lee Ells (Ed) New Yolk Praeger, 1992d

Of human bonding cooperation or explottation? Social Science Information, 31 611642, 1992b 
- Medieval mongamy In Darn tman Approaches to the Past. S Mithen and H Maschner (Eds) New York Plenum, 1992c

- The point of politics production or reproduction? In Sociobiology and Soc tologi, Edgar Dahl (Ed) Special issue of Analyse and Kritk, 15, 1992d

- Lombardo, L Who's pro-choice and why? Ethology and Socrobiology 12 49-71 1992

- and Weber, S Polygyny in American Politics Politics and the Life Sctences 16. 1992

Boone, J Parental investment and elite family structure in preindustrial states a case study of late medieval-early modern Portuguese genedogıes American Anthropologist 88 859878,1986

Boswell, J The Kindness of Strangers, New York Pantheon, 1988

Bradley, K Discovering the Roman Family Studies in Roman Social Histon, New York Oxford University Pres, 1991a

- Remarriage and the structure of the upper-class Roman family In Marrage, Divorce, and Children in Ancient Rome, B Rawson (Ed) Oxford Clarendon, 1991b

Broude, $G$ and Greene, $S$ Cross-cultural codes on twenty sexual attıtudes and practices Ethnologv $15 \quad 409-429,1976$

Brown, P Late antiquity In From Pagan Rome to Byzantum, Volume 1 in G Duby and P Aries (Eds) A History of Private Life, Cambridge Belknap, 1987

- The Body and Soctety Men. Women and Sexual Renunctanon in Early Christanty, New York Columbıa Unıversity Press, 1988

Brundage, J Law. Sex, and Christlan Soclety in Medieval Europe, Chicago Unıversity of Chicago Press, 1987

Brunt, P A Italian Manpower 225 BC-AD 14, Oxford Clarendon Press, 1971

Buss, D The Evolution of Human Matıng, New York Basic Books, 1992

Cantarella, E Homicides of honor the development of Italıan adultery law over two millennid In The Family in Italy, D Kertzer and R Saller (Eds) New Haven Yale University Press. 1991

Carcopıno, J Dally Life in Ancient Rome, translated by E O Lorımer London Routledge and Sons, 1940

Champlın E Final Judgements Duty and Emotion in Roman Wills, Berkeley University of Calıfornia Press, 1991

Charnov, E The Theory of Sex Allocation, Princeton Princeton University Press, 1982

Cicero, Marcus Tullıus De Oratore, translated by H Rackham Cambridge Harvard University Press, 1960

Clutton-Brock, $T$ and $V_{1 n c e n t, ~}$ A Sexual selection and the potentidl reproductive rates of males and females Nature 351 58-60, 1991

Cohen, D The Augustan law on adultery the social and cultural context In The Family in Italy, D Kertzer and R Saller (Eds) New Haven Yale Unıversity Press, 1991

Corbett, P The Roman Law of Marrage, Oxford Clarendon, 1930

Corbier, $M$ Divorce and adoption as Roman familal strategies In Marrage, Divorce, and Children in Anctent Rome, B Rawson (Ed) Oxford Clarendon, 1991a

- Constructıng kınshıp in Rome Marriage and divorce, filıatıon and adoption In The Family in Italy from Anuquity to the Present D Kertzer and R Saller (Eds) New Haven Yale University Press, 1991b

- Family behavior of the Roman aristocracy In Women', History and Ancient History, S Pomeroy (Ed) Chapel Hill Unıversity of North Carolına Press, 1991c

Crook, J Law and Life of Rome, Ithaca NY Cornell University Press, 1967

- Feminine inadequacy and the Senatusconsulum Velletanum In The Family in Anclent Rome, B Rawson (Ed) Ithacd Cornell Unıversity Press, 1986

Csıllag, P The Augustan Law's on Family Relatıons, Budapest Akadémıa Kıadó, 1976

Daly, $M$ and Wilson, M Homicide, Hawthorne NY Aldine, 1988

Darwın, C On the Origın of Spectes, New York Modern Library coriginally London John Murray), 1859

—_ Selection in Relation to Sex, New York Modern Library (orıgınally London John Murray), 1871

Daube, D Roman Law Lingutstc, Social and Philosophical A spects, Edınburgh Edınburgh University Press, 1969

Dickemann, M Female infantıcıde, reproductıve strategıes, and social stratıfication A prelım- 
inary model In Evolutionam Buology and Homan Social Behan wo An Anthopological Pespectue $N$ Chagnon and $W$ Irons (Eds) North Scituate MA Duxbury Press. $1979_{\mathrm{d}}$

The ecology of mating systems in hypergynous dowry societies Soctal Science Information $18 \quad 163-195 \quad 1979 \mathrm{~b}$

- Paternal confidence and dowry competition A brocultural analysos of puidah In Vatural Selectom and Soctal Behaum Recent Research and Nen Theom R D Alexander and D W Tinkle (Eds) New York Chıron 1981

The Digest of Justinan translated by Alan Watson Philadelphid Universits of Pennsylvania Press 1985

Dio Cassius Hustoly translated by Earnest Cary New Yolk G P Puinam Sons 1925

Dixon, $S$ Breaking the lau to do the right thing the gradual erosion of the Voconian law in ancient Rome Adelade Lan Revew $9519-534$ 1985d

The marlage allance in the Roman elite Jormal of Famh Hotsm $10 \quad 353-378$ 1985b

The Roman Mothe' London Croom Helm 1988

The Roman Famih Balumore Johns Hopkins 1992

Drijvers J Virginity and asceticism in late Roman Westein elites In Sulad Awmmen J Blok and P Mason (Eds) Amsterdam J C Gleben, 1987

Duby G Mederal Manage, Baltmone Johns Hopkms Unversity Press 1978

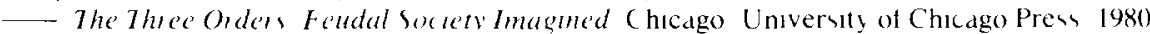

- The Knght the Lad, and the Plest The Makme of Modern Maliage th Mederat Franc t tanslated by Barbara Brav New York Pantheon, 1983

Etrenne R Le demographedes des familles imperlals et senatoriales au IV siecle apies J C Transtomation et Conflit an IV sterle ap J-C Antiquitas Reshe 1 Band $29133-$ 1681978

Eyben, E Fathers and sons In Mantage Dnom(a, and Chlden in Anctent Rome B Rauson (Ed) Oxford Clarendon 1991

Flinn M Uterine versus agnatic kınship variability and assoclated cousin matulage preterences an evolutionary biological analyas In Natural Selectomand Soral Beharam, R Alexander and D Tinkle (Eds) New York Chiron, 1981

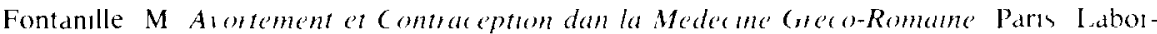
dtorres Searle 1977

Frank R Augustus legislation on marriage and children Californa Studie's in Classal Antanuth 8 44-52 1975

Friedlander, L Roman I te and Mamnes Linder the Lah Empue, tianslated by I eonard Magnus Neu York Arno Press (orlginally London George Routledge) 1908

Galınsky K Augustus legislation on morals Phlologm $125 \quad 126-144 \quad 1981$

Gardner J Women th Roman I aw and Soctet, l ondon Croon Helm 1986

Garney, P Soctal Status and Legal Prvtlege th the Roman Emptre Oxford (larendon 1970)

- and Saller, R The Roman Empue Econom Socte'l and Cultue, Berkeley L niversity of Californid Piess. 1987

Gaulun $S$ and Boster J Dowry as female competition Amencan Anthropologest 92 994-1005 1990

- and Schlegel A Paternal confidence and parental investment a cross-cultural test of a sociobiological hypothesis Ethologs and Socwobolog I 301-369 1980

Goody J Strategies of herrship Comparatue Studics in Soctoty and Hastom 15 3-20 1973

Inheritance, property and women some comparative considesatoms In Famil and Inhertance Rural Soctets in Western Eumope $1200-1800$ J Goody I I hirsh and E P Thompson (Eds) Cambridge Cambridge University Press 1976

The Delolupment of the Fambl and Marnage in Earope Cambridge Cambridge IInversity Press 1983

Gratwick, A tree or not so tree 'Wives and daughters in the late Roman republic In Mamage and Propeit). E Crak (Ed) 1984

Hallett J Fathe's and Daughters in Roman socten Princeton Princeton University Piess 1984

Hamiton W D The genetic evolution of social behaviot Jounal of Theonetual Buologt 7 521964

Hartung J Polygvny and the inheritance of wealth (urrent Anthropolog $23 \quad 1-12 \quad 1982$

- Matrilineal inheritance new theory and andysis The Behavioral and Bran Sciences 8 $607-622 \quad 1985$ 
Harris, W The theoretical possibility of extensive female infanticide in the Graeco-Roman world Classical Quarterly 32 114-116, 1982

Hopkıns, $\mathrm{K}$ Contraception in the Roman Empire Comparatve Studies in Societv and History $8 \quad 124-151,1965 \mathrm{a}$

The age of Roman girls at marriage Population Studies 18 309-327, 1965b

- On the probable age structure of the Roman population Population Studies 20 245-264. 1966

Conquerors and Slaves, Cambridge Cambridge University Press, 1978

- Rrother-uster marriage in Roman Fgypt Comparatuve Studes in Societv and Historv 22 $303-354,1980$

- Death and Renewal, Cambridge Cambridge University Press 1983

Horace Odes and Epodes, translated by Niall Rudd Harmondsworth Penguin, 1979

Hrdy S B Sex-bidsed parental investment among primates and other mammals a critıcal review of the Trivers-Willard hypothesis In Blosocial Perspectuves on Child Abuse R Gelles and J Lancaster (Eds) Hawthorne NY Aldıne-de-Gruyter, 1987

Humbert. M Le Remariage á Rome, Milan, 1972

Juvenal The Sixteen Satires, translated by Peter Green Harmondsworth Penguin, 1974

Kiefer, O Sexual Life in Anctent Rome, London Routledge and Kegan Paul. 1934

Last, H The social policy of Augustus Cambridge Ancient History x 425-64, 1934

Lattımore, Richard Themes in Greek and Latin Epitaphs, Urbana University of Illınols, 1942

Low, B Measures of polygyny in humans Current Anthropolog 29 189-194, 1988

Martial Epigrams, J A Pott and F A Wright provide the complete translation London George Routledge and Sons, n d All direct quotes are drawn from James Michie's translation Harmondsworth Penguin, 1978

McNamara, $\mathrm{J}$ A new song celibate women in the first three Christian centuries Women and History 6/7 38-140, 1983

Mommsen, T Romisches Strafrecht Graz Akademische Druk- und Verlagsanthalt, 1955

Murdock, G P Ethnographic Atlas, Pittsburgh HRAF Press, 1972

Oldenziel, R The historiography of infanticide in antıquity A literature stıllborn In Sevial A svmmetrv, Josine Blok and Peter Mason (Eds) Amsterdam J C Gieben, 1987

Ovid The Love Poems, includes Amores. The Art of Love, and The Cures for Love, translated by A D Melville New York Oxford University Press, 1990)

Padden, R The Hummingbud and the Hawk, Columbus Ohio State University Press, 1967

Patlagean, E Byzantum in the tenth and eleventh centuries In From Ancient Rome to Byzantium, P Veyne (Ed) Volume $1 \mathrm{in} \mathrm{G} \mathrm{Duby} \mathrm{and} \mathrm{P} \mathrm{Arres} \mathrm{(Eds)} \mathrm{A} \mathrm{Histon} \mathrm{of}$ Private Life, Cambridge Belknap 1987

Petronius The Satyricon, translated by J P Sullivan Harmondsworth Penguin, 1986

Pliny the Elder Natural Histor, translated by H Rackham Cambridge Harvard University Press, 1962

Plıny the Younger Letters, translated by Betty Radice Harmondsworth Penguın. 1969

Polybius Historles translated by W R Pdton New York G P Putnam's Sons, 1927

Pomeroy, S B Goddesses, Whores, Wwes, and Slaves Women in Classical Anttquity. New York Schocken Books, 1975

Power E Medieval English Nunnerles, Cambridge Cambridge University Press, 1922

Rawson, B Family life among the lower classes at Rome in the first two centuries of the Empire Classical Philology, 61 71-83, 1966

Roman concubinage and other de facto marriages Transactions of the American Philological Association $104 \quad 279-305,1974$

- The Roman family In The Famlv in Ancient Rome New Perspectives, B Rawson (Ed) Ithaca NY Cornell University Press, 1986

Spuru and the Roman view of illegitimacy Anttchthon 23 10-41, 1989

- Adult-child relationships in Roman society In Marriage, Divorce, and Children in Anctent Rome, B Rawson (Ed) Oxford Clarendon, 1991

Redford, D Akhenaten The Heratı King. Princeton Princeton University Press, 1984

Rouselle, A Porneia On Desires and the Body in Antiquty, translated by Felicia Pheasant New York Basil Blackwell, 1988

Saller, R Roman dowry and the devolution of property in the Principate Classical Quarterly 34 195-205, 1984a 
Famila domus, and the Roman concept of the tamily Phoenix $38 \quad 336-355 \quad 1984 \mathrm{~b}$

Men's age at marriage and its consequences in the Roman family Classual Phlology 82 21-34, 1987a

Slavery and the Roman tamily In Classual Slaten M Finley (Ed) London Frank Cass, $1987 \mathrm{~b}$

- Roman heirship strategies in principle and in practice In The Family in Italv from Antiquat to the Piesent D Kertzer and R Saller (Eds) New Haven Yale Universily Piess 1991

Scriptores Hotonae Augustae translated by David Magie Loeb Classical Library London William Heinemann, 1922

Seneca L A On Benefits, translated by Aubrey Stewart London George Bell and Sons, 1900

Shaw B The famıly in late antıquity The experience of Augustıne Past and Present 115 3$51 \quad 1987 d$

- The age of Roman girls at marriage some reconsiderations Jounal of the Rotal Soctety $77 \quad 30-46 \quad 1987 b$

- The cultural meaning of death Age and gender in the Roman tamily In The Famls in ltals from Antiquat to the Present D Kestzer and R Saller(Eds) New Haven Yale University Press 1991

- and Saller R Close kin marriage in Roman society' Man 19 432-444, 1984

Soranus Ginaecology translated by Owseı Temkin Baltımore Johns Hopkıns Press, 1956

Stone. L The Famih Sex and Marrage in England 1500-1800 Abridged edition New York Harper and Row 1977

Suetonus The 7uelve Caesas translated by Robert Graves revised by Michael Grant Harmondsworth Penguin 1982

Syme. R The Roman Retoluthen. Oxford Oxtord Unversity Press 1939

The Aagustan Amstocrat, New York Oxford 1986

- Marrage ages for Roman senators Histoma $36 \quad 318-332 \quad 1987$

Tacitus The Annals of Imperial Rome, translated by Michael Grant Harmondsworth Penguin. 1989

- Agricola and Germania translated by $\mathrm{H}$ Mattıngly, revised by S A Handford Harmondsworth Penguin 1988

Thornhill N W A cross cultural study of human inbreeding Behatoral and Bram Sciences 1991

- Thornhill, R An evolutionary analysis of psychological pain following rape I Etfects of victim's age and marital status Ethologi and Socobologi 11 155-176, 1990

- and - An evolutionary andlysis of psychological pain following rape II The eftects of stranger friend, and family-member offenders Erhologi and Socobologi 11 177193, 1990

Treggları, S Roman Flecimen Durmg the Late Republic Oxford Clarendon, 1969

Jobs in the household of Livid Papes, of the Britsh Sehool at Rome 43 48-77 1975

- Jobs for women Americ an Joum nal of Ancient Histor 1 76-104 1976

- Concubinde Papen of the Britsh School at Rome 49 59-81 1981

- Digna condicio Betrothals in the Roman upper class Classeal beu, $3419451 \quad 1984$

- Women as property in the edrly Roman Empire In Women and the I a w volume $2 \mathrm{D} \mathrm{K}$ Weisberg (Ed) Cambridge MA Schenkman, 1982

- Roman Marrage Iusti Conuges From the Ime of Cicen whe Time of Ulpran, Oxford Clarendon 1991a

- Ideals and practicalities in matchmaking in Ancient Rome in The Famil in Italy from Antiquat to the Present D Kert/er and R Saller(Ed, I New Haven Yale University Piess, $1991 \mathrm{lb}$

- Divorce Roman style how easy and how frequent was it' In Marrage Duorce and Chuldren in Ancient Rome, B Rawson (Ed) Oxford Clarendon 1991c

Truvers, R L Parental investment and sexual selection In Sexal Selection and the Descent of Man 1871-1971 B Campbell (Ed) Hawthorne NY Aldine 1972

- Socal Evolution, Menlo Park CA Benjamın/Cummıng, 1985

and Willard. D Natural selection of parental ability to vary the sex ratio of offspring Sctence 179 90-92, 1973

$\mathrm{Van}$ den Berghe, $\mathrm{P}$ and Mesher, $\mathrm{G}$ Royal incest and inclusive fitness Amencan Ethnologist $\begin{array}{lll}7 & 300-317 & 1980\end{array}$ 
Veyne, P The Roman Empure In From Pagan Rome to Byzantum, Paul Veyne (Ed) Translated by Arthur Goldhammer Volume one in Phılippe Ariés and Georges Duby (Ed) A History of Private Life, Cambridge MA Harvard University Press, 1987

Wallace-Hadrill, A Family and inheritance in the Augustan marriage ldws Proceedings of the Cambridge Philologic al Soctety 27 58-80, 1981

- The social structure of the Roman house Papers of the British School at Rome 56 4397, 1988

Watson, A Roman Slave Law', Baltımore Johns Hopkıns Unıversity Press, 1987

Westermann, W The Slave Systems of Greet and Roman Antiqutr. Philadelphid American Philosophical Society, 1955

White, D Rethinking polygyny co-wives, codes and cultural systems Current Anthropology $29529-558,1988$

Wiedemann, T Greek and Roman Slavery, Baltımore Johns Hopkıns Press, 1981

- Adults and Children in the Roman Empire, London Routledge, 1989

Willams, G C Adaptation and Natural Selection A Critique of Some Curent Evolutionary Thought, Princeton Princeton Unıversity Press, 1966

Willams, G Some aspects of Roman marriage ceremonies and ideals Journal of the Roval Socletv 52 28-46, 1962 